\title{
Evaluating ascertainment proofs obtained through illegal means
}

\section{Mina Mehrvand ${ }^{1}$ and Khalil Afandak ${ }^{2}$}

\author{
1 Department of Law, Ilkhchi Branch, Islamic Azad University, Ilkhchi, Iran \\ E-mail: mi.mehrvand@gmail.com (iD http://orcid.org/0000-0003-2662-1908 \\ 2 Department of Law, Ahar Branch, Islamic Azad University, Ahar, Iran \\ E-mail: kh.afandak@gmail.com (iD) http://orcid.org/0000-0002-6900-7193
}

\begin{abstract}
A criminal act must be proved by legal reasons, but in addition to the necessity of legality of the reasons, the ways for obtaining the reason should not be in violation of the law. In Iran's criminal code, there are relatively detailed rules on the grounds reasons to prove crime and legal grounds for their probative powers but there is no systematic approach to obtaining reason in Iran's penal code and this leads to a difference in the value of the evidence obtained in contravention of the law. The new Criminal Procedure Code stipulates new rules on the value of evidence obtained in illegal ways. For this reason, the present thesis deals with research and study on the evaluation of evidence obtained in contravention of law and in this regard, we have investigated the declarative reasons (confessions, testimonies, oaths and testimonies) and acquiring reasons(inspections and tricky police actions) obtained through illegal means and this is the result of the fact that the declarative evidence obtained in a way contrary to the law has not legal value But there is no ban on tricky police actions in Iranian criminal law and the Iranian law's stance on unlawful inspections is ambiguous.

Keywords: Declarative reasons. Acquiring reasons. Tricky actions. Criminal procedure.
\end{abstract}

\section{INTRODUCTION}

The gravity center of claims is reason. The place and significance of reason in claims, especially in criminal claims, is unimaginable. Obtaining the reason is one of the basic and fundamental issues of the criminal procedure; as long as there is no reason for the imposition of a crime and, consequently, the execution of the punishment does not exist. Reasoning in criminal affairs is more important than other issues. Because it faces the fundamental guarantees of the rights of individuals, in particular the law of imprisonment, which can be affected. Therefore, the proofs in criminal matters are of great importance.

Reason has two parts: declarative and ascertainment. Ascertainment reason is a reason that exists in the outside world, and the judge will act as a foreign matter and the declarative reason is that it was happening in the presence of the judge in the form of a report of what happened in the pastand the judge will hear the news from the area of the people (Karimi, 2010).

Sometimes the reason is declarative, that is, the judge is waiting for the news of the persons involved in the lawsuit or third parties to determine the case accordingly. Like confessions that are right news, is in favor of others and self-harmful or be witness is right news,is in favor of others and selfharmful or swearing is right news, is in favor of others and self-harmful by with the witness of the Almighty God. In fact, the oath 
of is the emphasized news because the news is affixed with the word of His Majesty.Because they all include news, they are called declarative. For declarative reason (in civil matters) the judge does not play a very active role (Bahrami, 2010). So, he can not as for example the parties, leads them to the confession in the form of guided questions or looks for a witness to encourage her to testify at the expense of one of the parties. Or, encourage one of the parties to swear allegiance, because in this case the principle of the impartiality of the judge will be violated. But in criminal matters the judge plays an active role in addressing the causes of the news and can ask witness several questions for crime detection and or the prosecutor can investigate but has particular duty to look for witnesses in unpardonable crimes or challenge other declarative reasons. In addition to the above three reasons that are always declarative some reasons sometimes include news. The document of the reason is reason. In fact, the document often involves confessions between the parties and the document itself is a reason for the past confession of its signatories so saying that document of the reason is reason. The document's content, when confessed, is a matter of declaration. While the document itself, as an external reality, is an ascertainment reason and the role of the judge in establishing authenticity of the document should be noticed as activated. Of course, in criminal matters, a document can be confiscated in rare cases and in most cases, the document in a criminal offense accounts as declarative reason (Karimi, 2010).

But in some cases, not only the document itself is the ascertainment reason which contains the reason that are ascer- tainment reason also. Such as aerial maps that document or record containing examination rooms and supply presumptionmemorandum and we know that some reason, such as presumptionare ascertainment reason, because the judge deals directly with the circumstances of the matter (Karimi, 2010). The local examination is also of a variety of judicial presumption.

On the ascertainment reasons it can be said that the expert is one of the ascertainment reasons. With this explanation in masters, judge with meddling of a person as an expert through the established fact. Local research is based on reasons that are of a mixed nature. I.e. it's both declarative and ascertainment. Is declarative news where locals and informed people know their information but ultimately, this is the judge who makes the point of his mind realizing the reality and the discovery. The document itself is always in place for ascertainment reasons. Although related to the reason reflected in it is also possible to speak about the ascertainment reason and also the declarative reason.

The scope of the value of the material causes obtained in a manner contrary to the law in Iran's law is more than the nonmaterial reasons discussed and controversy since the legislator has taken a stance on the immaterial reasons, but there are ambiguities about the ascertainment reasons which in this paper, in the form of two general sections (cagily actions, audits and inspections), material evidence obtained through illegal ways is evaluated.

\section{EVALUATION OF ACHIEVED REASONS THROUGH CAGILY ACTIONS}

According to paragraph 7 of Article 4 of 
the Law of the Islamic Republic of Iran's Law Enforcement approved of 1369, one of the duties of the police is to prevent crime. An important part of police measures and missions is also to prevent crime. Obviously, crime prevention is far more important and more important than crime detection. The natural consequence of failure to prevent crime, the increase in the rate of crime and the aggravation of the burden of the officers responsible for the detection and prosecution of crime and, in general, more harm to the community. In implementing the trapping, if the police officer simply fails to commit a crime simply by provoking an officer, the police will not only avoid the prevention objectives, but will also facilitate the prosecution of crime. But in the hypothesis that the police are faced with a number of individuals, including repeat offenders, there is no conflict between trapping offenders and targets for crime prevention; because in this case, police behavior is nothing but identifying these criminals and uncovering the truth.

Trapping crime detection methods is in conflict with the law of entrapment and good morals. Can the police go to law to enforce and enforce the law? For example, in the hypothesis that the police, with the background of the preceding, identify the person to the doctor, psychiatrist, expert, or ... and then receive his secrets from the above persons, his Chinese background reveals the head the direction of these people becomes. Does the even level of police with the criminal, is aligned with the dignity of the police profession? Can the police hide their identity during the law enforcement (especially the crime detection)? Today, police officials emphasize that the police must reveal their identity to the audience before taking any action.

Police are manifestations of governance and should not act on behalf of the government in a way that prohibits others from doing so. (It may be possible to carry out trapping, deplorable escape from law enforcement.) Has the use of trapping by the competent authorities been clearly disclosed to the general public? Because the main purpose of the police in the first place is crime prevention, and in the next stages, it is the discovery and prosecution of crime, and in this regard, it is important to perform psychological operations. Is the offense committed by the perpetrator the result of a method used by the police to detect a crime? (Sufferstein, 1999). An effective police crackdown would cause crime? Is the livestock tract only used to detect major crimes, or does the police use it as a means of detecting all crimes? Is the only way to discover the crime of the police, is trapping? However, if the police violate the rules and regulations governing the use of garments approved by the law, disguised as a result of the incitement and persuasion of the person concerned, he would be the victim of the crime. His behavior does not match the professional ethics of the police. This issue is apparently twofold in a situation where the detection of crime by other methods is practically possible and the intended crime is not so important. In terms of criminal liability, what is the situation of the police officers who have committed such an act? Does the police make a criminal offense in the form of a formal deal (in some animal breeding farms)? Obviously, police officers do not intend to commit a crime in carrying out these formal acts, so the crime will not be prosecuted by the agents. Otherwise, the police will commit 
the same crime that the perpetrator has committed and in Iran's penal code (even under the new Criminal Procedure Code), reference to the justification for the crime by police officers has not been discovered. Theoretically, if the prosecutor proves that the effective provocation of the police has caused the crime, the officer may be charged with the charge of the deputy in the crime (Mazaheri, 2006).

In any case, however, it should be noted that in order to maintain the security of the country, police cannot be prohibited from trapping absolutely, in particular, in current Iranian legislation, crime detection is not explicitly prohibited in such ways is not explicitly prohibited. But it is worth noting that the use of methods such as trapping is limited to discovering significant crimes that hurt the high interests of the country or endanger the security of the country. Today, committing crimes such as money laundering, human trafficking, terrorism, drug trafficking, corruption, etc. is one of the major concerns of the human community. The new criminal law approach to this kind of crime is such that in addition to intensifying legal penalties in dealing with perpetrators of such crimes, sometimes some basic principles of criminal proceedings are also challenged (Mohseni, 2010).

\section{APPROVING VALUE OF THE REASONS DERIVED FROM TRAPPING}

According to the current rules, the prosecution system in Iran is a system of prosecutors and courts, and according to Article 156 of the Constitution and Article 22 of the Criminal Procedure Code, detecting crime and the burden of proof is on the prosecution service. The issue that appears in this section more than anything else is the proof of the claim. We know that proving every claim requires reasons. On the one hand, the criminal judge is free to study for any positive cause of the claim. He is authorized to accept any persuasive reason. But there is difference between "reason as a means of proving crime" and "ways to obtain a cause", such as an investigation and examination, recording and listening to telephone conversations, and so on (Ashoori, 2009). For example, "confession" is considered as one of the most important reasons for a crime, but if the confession is obtained through torture or coercion, it is considered to be worthless under Article 38 of the Constitution. Hence, along with the principle of the freedom of the criminal judge, in obtaining any kind of evidence of a crime, there are precise and complicated rules on how to obtain reasons for him. In this regard, consideration of the credibility and accuracy of the reasons given by the judicial authorities is important. Obtaining the reason is the responsibility of the prosecutor (the prosecuting authority), and with the referral of the investigation by them is the responsibility of the judiciary; officers are required to collect any useful information to discover the truth; this stage is due to the precise and sensitive stages of criminal proceedings, and the rights and freedoms of the accused may be subject to arbitrariness (Akhondi, 2000). In accordance with the principles adopted in the Criminal Procedure Code, preliminary investigations by the Prosecutor's Office should always be conducted in the light of respect for the principle of innocence, the right to defend the accused and the principle of the interpretation of doubt in favor of the accused and based on respect for human rights and 
the judiciary and away from any insult to human dignity and dignity. However, the reasons that are met by following the rules and are lent to its observance are correct and legitimate and have legal effects. Based on the issues discussed and in a general summary of cunning actions in detecting a crime, it is worth while to say that trapping for discovery is contrary to public order and ethical standards. In the trapping plans, the crime is committed by the police, so the perpetrator (the person whose crime has been discovered by the trapping method) is deemed responsible. In the event that police provocation is effective and causes the crime to be committed, in spite of other circumstances, police officers will be charged with assassination charges by the perpetrator. If the accused, under the influence of an effective provocation by the police, commits a crime, the court can reduce the punishment of the perpetrator by issuing the sentence. Considering the importance and priority of maintaining the security of the country on other issues, if other methods of crime detection are not effective, one of the most effective methods of detecting crimes that harm the country's top interests (Such as money laundering, human trafficking, terrorism, etc.). Hence, given the specific nature of these crimes and the new criminal law approach in this regard, In the case of legislative measures and approval of precise rules, the detection of these types of crimes is permitted through trapping. The reasons for trafficking, for many crimes, lack credibility and accuracy to prove the crime (such as kidnapping, robbery).

\section{APPROVING VALUE OF THE REASONS DERIVED FROM UNLAWFUL INSPECTIONS}

Concerning the illegal acquisition of reason, inspection and inspection is one of the most controversial reasons and given that these actions are being carried out by judicial authorities, and these agents may be excluded from legal review in the inspection and inspection, the question is always about the police inspection and inspection that does the reasons obtained from inspection, have correct and legal procedures and observance of the rules? Inspection involves different things, but home and vehicle inspection are more important than this.

Before examining the stance of Iran's legislation in this regard, one of the admirable votes and prior consideration of the value of the report of the defendants regarding the audit and inspection is mentioned, however, such rhetoric is so rare and fewer court judges consider the process of gaining reason, but such a proposition suggests the possibility of the attention of all judges to this:

\section{Judgments No. 9609972649000076}

Regarding the charge of men .... lack of a criminal record for carrying alcoholic beverages, regardless of the statements of repentance and their remorse at the hearing, since according to the second part of Article 55 of the Criminal Procedure Code, the inspection of persons and objects in nonevident offenses is subject to judicial authorization and in this case, according to the report of the defendants and the evidence available, as well as the statements of the defendants regarding the inspection 
of the vehicle's rear trunk, there was no such thing. The court does not pay attention to obtaining illegal grounds (in terms of form), as well as Article 36 of the Criminal Procedure Code that the credibility of the report is bound by two fundamental constitutions and based on its second partreports must be prepared and regulated according to legal requirements and regulations, considers the charge to be distorted by these people. On the other hand, it does not morally agree that violating the spirit of the Criminal Procedure Code based on the necessity of legality to obtain reasons for reasons, based on the reasons for which the legislator has been bannedor at the same time allowing it to be obtained illegally and in violation of the principle of the legitimacy of studying the reason. Therefore, the reasons given are not present and are out of the question and along with the provisions of Articles 2, 7, 36, 61 of the Code of Criminal Procedure and Articles 120 and 121 of the Islamic Penal Code and the Principles of Islamic Penal Code, the Court (as the judicial representative of the Islamic holy system of the Islamic Republic) protects the privacy of citizens. Thirty-seven of the constitution of Iran issued and pronounced a verdict against all defendants.

Since the judicial procedure is a legislative procedure, it is also worth while to express our criticism of the judicial process, which remains meaningful in doubt. In the court's opinion, it should be said that the legislator's prohibition in this regard was only a decree against the agent and does not cause corruption and ruin of the subject matter (reasons) of the educated, is clearly vague and merely a license to uphold the privacy of citizens. Now that nearly 38 years of rule of law in the Islamic Republic of Iran is underway, citizens cannot be told that you do not have the right to be heard, but if you get information through illegal and unlawful listening, you can cite them, if so, the prohibitions do not have a guarantee of execution. Even morally, the legislator cannot forbid the practice, but finds its results acceptable, because it is a kind of abolition of speech and away from the holy lawyer and the wise legislator.

Of course, this vital point should not be forgotten that judicial procedures in dealing with illegitimate reasons must be distinguished between the right to God and the right to a religion and the reasons for it being published and enforced. Obviously, the discovery of the crime of murder in an illegal manner is so important that the existing reasons must be taken into consideration, with the explanation that if the reasons for illicit education are reasons for the news, such as confession, testimony or oath of torture, undoubtedly, the reasons given will, in addition to the punishment of the agent, be unreliable, but if the reasons for the illegal obtainment of the reasons are fulfilled, it could be indicative of the conviction.

\section{EVALUATING THE REASONS DERIVED FROM HOUSE ILLEGAL INSPECTIONS}

The Iran's Criminal Procedure Code, passed in 1999, provides for a home inspection: "inspection of homes, places and objects shall be carried out in cases where there are reasons for strong suspicion to disclose the accused or equipment, and the reasons for the crime there". In addition, Section 24 of the Criminal Procedure Code stipulated the following:" Inspections of homes, places, objects and individuals in 
non-obvious crimes should be subject to a judicial authorization, although investigations generally have been referred to the courts by the judicial authority". The new Criminal Procedure Code provides a more comprehensive approach and more precise criteria for home inspections. According to Article 58 of the Criminal Procedure Code: "Judicial authorities shall, when entering the houses, closed and closed places, present the documents of the judicial documents to the location of the custodian while presenting the identity papers, indicating the cases in the form of the petition, and signed by the person Or the present ones ... " Article 140 stipulates: "Inspection and inspection of the house shall be carried out on a day-by-night basis and shall be carried out at night only if the necessity of the requisite condition is met. The prosecutor shall state the reasons for the necessity and shall in the matter of the matter and, if possible, be present at the place. Find out Note-day is from sunrise to dusk. "

The legislator, with a positive attitude in the new Criminal Procedure Code, has tried to make house inspections more carefully to protect the privacy of individuals who are immune from bullying. In keeping with privacy, the new Criminal Procedure Code also imposes restrictions on judicial authorities, requiring judicial authorities to specify in detail and in detail the subject of the inspection until they have been issued an inspection order and Avoid general inspection. In this regard, Article 141 stipulates that: "The order of the judicial authority for entering the home, closed and closed places, should be the subject under each heading, and the subject matter for inspection, time, times of arrival, property, places and address they are explicitly identified. In ac- cordance with the instructions of the judicial authority, the officials are required to set the quality of the audit and inspection and the outcome in the form of a bill of rights, sign it or fingerprints, and declare the cases to the judicial authority within a maximum of twenty-four hours. "

Article 142 of the Criminal Procedure Code provides for the further protection of individuals' private rights and respect for privacy: "Inspection and inspection of the home or residence of persons in the presence of the attendant or senior, and, if necessary, with the presence of witnesses, while observing The religious and legal standards, the maintenance of the order of the place are inspected and the respect of the sanctity of the inhabitants and its neighbors.

Note - When there is no one at the checkpoint, in case of urgency, the inspection shall be carried out in the absence of detainees and residents of the locality, with the presence of two local residents, and shall be immediately determined on the face of the matter. "

Article 146 of the Criminal Procedure Code, in line with the emphasis on the greater respect for the privacy of individuals: "From the papers, writings, and other objects belonging to the accused, only obtain information about the crime and, if necessary, intuition Research is provided. The investigator is required to act with caution in the case of other writings and objects belonging to the accused, exposing the content and their non-related content to crime, otherwise he will be convicted of the disclosure of secrets. "

Legislator in the Code of Criminal Procedure, in a measure that has not had a precedent in Iran's penal code, has established 
rules for damage to property during an inspection and inspection process in a way that Article 145 provides: "If the home keeper, the place or objects to be inspected refuses to open the closed premises and objects, the investigator may order their reopening, but to the extent that the possibility of damages should be avoided.

Note - In the event that material damage occurs in the implementation of this article and is issued on the basis of a definite decision of the court imposing a prohibition or suspension of prosecution or a judgment of innocence, also, in cases where the refusal of a person is not a criminal offender, even if the matter results in the conviction of the accused, the state is responsible for compensation, unless it is established by the Bailiff or other agents that, in this case, the state compensates and the investigator and Or guilty agents. "

In order to protect the rights of citizens and to observe the legal principles of obtaining the reason, Article 137 of the new law provides two important conditions for issuing permits for inspection and inspection of the home: 1-Evidence and Emirates in the case of the presence of the accused or the discovery of the machinery and equipment and the reasons for the crime; 2 - strong suspicion of the presence of the defendant or the discovery of the equipment, the reasons for the crime. The investigator and other judicial authorities, having obtained the two conditions, can issue an audit order, otherwise they commit an offense.

\section{EVALUATING VEHICLES ILLEGAL INSPEC- TIONS}

In most countries, there are certain regu- lations regarding vehicle inspection, but no special rules have been laid down in Iranian law for inspection of vehicles. The Code of Criminal Procedure Act of 1378 did not mention any car inspecting, and therefore there were strong differences of opinion regarding the possibility of inspection of vehicles without obtaining permission from the judicial authority. In the Code of Criminal Procedure, only in Article 55 is a general reference to vehicle inspection.

Advanced countries have specific regulations for car inspections. For example, in the United Kingdom, there should be reasonable grounds for the United States and the UAE before car inspections. Police officers can only inspect a vehicle where there are strong grounds for using the vehicle to commit a crime or carry banned material; in addition, in this case, the minimum operating intensity should be used and avoid using it until it is necessary to use it (Farajiha, Yari, 2012). In order to prevent possible abuse, it is stipulated that only an official police officer can stop and inspect cars; therefore, drivers are not required to stop if the police officer does not wear formal suits. In cases where inspections of vehicles are necessary, but the defendant is not present, certain provisions are foreseen to comply with his rights. In this case, the police officer is required to insert a sheet in the vehicle after inspection. In this sheet, the following should be recorded: 1 . The vehicle has been inspected; 2 . The name of the officer who inspected; 3 . The police unit that the inspecting officer serves and the person can apply for damages 4 ) has the right to make a copy of the note relating to the inspection minutes. The criteria are foreseen that the owner of the vehicle might encounter a car confusion after being 
present at the inspection site. Compliance with these regulations reduces her concern and, if protested, can object to the illegality of the inspection; in addition, the inspection shall be carried out in the shortest possible time and at a place close to the place where the car is stopped. The recent requirement should also be observed in the inspection of individuals (Barani, 2009).

\section{VALIDITY OF VEHICLES INSPECTION IN THE CRIMINAL PROCEDURE CODE}

Regarding the vehicles inspection, Article 55 of the Code of Civil Procedure is in effect in Iran's law, in this way it provides: "... the inspection of persons and objects with a judicial authorization is a judicial authority ..." The term "objects" in this it is a general material and includes vehicles. Therefore, according to the above law, the general rule in Iranian law regarding vehicle inspection is that: inspection of vehicles for evidentiary crimes does not require obtaining a license from a judicial authority, but a case should be obtained from non-verifiable crimes for inspection of vehicles. The former Criminal Procedure Code did not explicitly refer to the issue of credibility of the report of the defendants regarding the inspection and inspection if the reasons were obtained from illegal means, and only Article 15 of the Criminal Procedure Code of the former criminal court considered the defendant's report valid if it was to be credible and credible by the judge. Some legal writers on the matter said that a search and inspection that was made without due observance of statutory requirements cannot be trusted and vindicated by the judge and with this notion, considered value reports collected by violating the rules and regulations relat- ing to the acquisition of reasons (Ashoori, 2009). But the fact is that Article 15 of the Criminal Procedure Code did not explicitly deal with this issue and the judicial process, for this reason, tended to be something thatin spite of the alleged violation of the rules in the preparation of the reports, they were issued a deceptive vote on these reports. The new procedural law in Article 36, concerning the limits of the validity and value of the report of the defendants of the judiciary, states: "the report of the defendant is valid only if it is not in accordance with the circumstances and the definitive evidence and is prepared in accordance with legal requirements and regulations". In this article, it is explicitly stated that if the statutory criteria for reporting are not met, they are not valid and worthless. But the most important shortcoming of the new criminal procedure law is that it has merely stated that reports that have been obtained through illegal means are null and void and despite the fact that invalidity of misleading reports has been made, the judicial process will continue to operate in the same way. Therefore, it was worthy for the legislator to go into more detail in this matter. Also, in article 36 , this is generally referred to; some judges consider the report's invalidity in the statutory regulation to be in line with the provisions of the reporting form and to reject the decree to abandon the illegal methods of acquiring the cause. Therefore, in analyzing the position of Iranian law regarding the value and credibility of the inspection and inspection of places and persons if they are illegally prepared, it should be said that the Iranian legislator's position on this issue is ambiguous and can be subject to various interpretations.

Therefore, in the present research, it 
should be said that in Iran, only two cases have explicitly denied the reasons provided by illegal means (void and untrustworthy testimony, confession and oath of allegiance to the suspect and deceptive questions) and regarding the reports prepared by the judiciary in an illegal manner due to the ambiguity and insight of the position of the Criminal Procedure Law, it cannot be stated that it explicitly defines the Iranian law stance on the lack of value of these reports. However, the above-mentioned law states the validity of the report of the defendants in complying with the rules in its regulation and preparation and one of the regulations is obtaining a permit from the judicial authority for inspection and inspection, however, the mechanisms for dealing with conflicting reports are not specified by law, and this could subject this provision to various interpretations.

\section{CONCLUSION}

In Iran's criminal justice system there is no general rule forjudicial value of the reason obtained through illegal ways. In general, there are two major approaches in the legal system regarding the value and validity of the reasons for illegal ways. Announcement of a criterion for measuring and assessing the reasons given in the criminal procedure process; indication of the cases of the lack of value of the reasons derived from violations of the law (inapplicable clauses). The law of Iran has chosen the second strategy, and in cases where the reasons given by the law is not worthy of value and has not announced a standard. If the reasons are obtained by way of a violation of law, it may invalidate the entire proceeding, or only unlawful reasons cannot be declared. Regarding the underlying principle of the lack of value, the reasons behind Iran's illegal ways should consider the point that (Unlike some countries, such as the United Kingdom) did not establish the main legislator in Iran's law, and only pointed to some of the reasons for it. Declarative reasons (confession, testimony, and oath) obtained by way of a violation of the law in Iran's criminal law explicitly deprives Article 38 of the Constitution of value and it is not possible to base judicial decisions on that basis.Therefore, if confession, martyrdom and oath are obtained through torture and coercion, they are not worthy of judicial value. There is no legal regulation on the prohibition or prohibition of cunning acts in the detection of crime by the police in Iranian law. But this should note that one of the important tasks of the police is crime preventionand trapping conflicts with this goal for detecting or arresting potential offenders so the decision to disallow such actions and, consequently, the lack of value of the reasons given in this way.

\section{REFERENCES}

Akhundi, M, Criminal Procedure. Volume 4, Qom: Ishraq Publications, 2000

Ashoori, M, Criminal Procedure. Volume 2, Tehran: SAMT, 2009.

Barani, M, Implementation of Physical Inspection in Iran and England Law. Tehran: Publications of the General Directorate ofNAJA Legal Education, 2009.

Bahrami, B, Reasons for Proving. Tehran: Cultural InstituteNegahe Bina, 2010.

Sufferstein, R, Secret police surveillance and surveillance from an adaptive point of view. Tehran: Imami translation, Naja Deputy Director, 2008. 
Karimi, Reasons to Prove the Claim. Tehran: SAMT Publication, 2010.

Farajiha, M; Yari, A, Validity of Reports Based on Inspection and Inspection, Detective Journal, No. 19, 2012.

Mohseni, $\mathrm{H}$, The concept of a judicial reference in Iranian law, Journal of Legal Justice, No. 79, 2012.

Mazaheri, AM, The concept of lawyer intervention in preliminary proceedings, Journal of Legal Justice, No. 56, 2006.

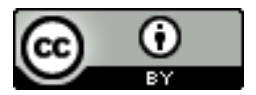
License information: This is an openaccess article distributed under the terms of the Creative Commons Attribution License, which permits unrestricted use, distribution, and reproduction in any medium, provided the original work is properly cited.

Article received on April 30, 2019.

Evaluated July 26,2019.

Accepted on August 05, 2019.

Published on August 07, 2019.

How cite this article (ABNT):

MEHRVAND, Mina; AFANDAK, Khalil. Evaluating ascertainment proofs obtained through illegal means. Estação Científica (UNIFAP), Macapá, v. 8, n. 3, p. 49-59, Sept./ Dec. 2018. 